CZASOPISMO INŻYNIERII LĄDOWEJ, ŚRODOWISKA I ARCHITEKTURY JOURNAL OF CIVIL ENGINEERING, ENVIRONMENT AND ARCHITECTURE JCEEA, t. XXXIII, z. 63 (3/16), lipiec-wrzesień 2016, s. 517-524

\author{
Beata WILK-SLOMKA ${ }^{1}$ \\ Janusz BELOK ${ }^{2}$
}

\title{
PARAMETRY OSZKLENIA A KOMFORT CIEPLNY W STREFIE O REGULOWANEJ TEMPERATURZE
}

\begin{abstract}
Streszczenie: Celem pracy było określenie wpływu parametrów oszklenia na komfort cieplny w wybranej strefie budynku. Jako strefę o regulowanej temperaturze wybrano fragment budynku jednorodzinnego o powierzchni ogrzewanej ok. $110 \mathrm{~m}^{2} \mathrm{z}$ dużą powierzchnią przeszkloną od strony południowej. Metoda badawcza przyjęta w pracy to badania numeryczne z wykorzystaniem programów EnergyPlus, OpenStudio, oraz Window. Dane klimatyczne niezbędne do przeprowadzenia obliczeń przyjęto dla miasta Katowice. W budynku założono funkcjonowanie systemu wentylacji mechanicznej z odzyskiem ciepła, a instalację grzewczą oparto na kotle gazowym zasilającym grzejniki płytowe, konwekcyjne. Ocenę komfortu cieplnego przeprowadzono posługując się wskaźnikiem PMV. W rozważaniach uwzględniono podział na pory roku (lato, zima) oraz porę dnia (dzień, noc) poprzez przyjęcie odpowiednich wartości opisujących aktywność fizyczną człowieka (met) oraz oporność cieplną odzieży (clo). Do analiz przyjęto 4 warianty oszklenia. Punkt odniesienia stanowi przeszklona fasada złożona z zestawu szybowego jednokomorowego wypełnionego powietrzem. Pozostałe warianty dobrano tak, aby odpowiadały współczesnym rozwiązaniom zestawów szybowych dla budownictwa niskoenergetycznego. Spełniają one aktualne wymagania izolacyjności termicznej, przy czym różnią się wartościami współczynników: przenikania ciepła U, całkowitej przepuszczalności energii promieniowania słonecznego g oraz przepuszczalności światła $\tau_{\text {vis. }}$ Są to zestawy trójszybowe, w których komory wypełniono argonem, szyby pokryto powłokami selektywnymi. Najbardziej korzystnymi z punktu widzenia uzyskania warunków odczuwania komfortu cieplnego dla opisanych powyżej założeń wydaje się być rozwiązanie W3.
\end{abstract}

Słowa kluczowe: wskaźnik PMV, oporność cieplna odzieży, aktywność fizyczna człowieka, średnia temperatura promieniowania otaczających przegród

\footnotetext{
${ }^{1}$ Autor do korespondencji / corresponding author: Beata Wilk-Słomka, Politechnika Śląska, Katedra Budownictwa Ogólnego i Fizyki Budowli, ul. Akademicka 5, 44-100 Gliwice; tel. 322372142; beata.wilk-slomka@polsl.pl

2 Janusz Belok, Politechnika Śląska, Katedra Budownictwa Ogólnego i Fizyki Budowli, ul. Akademicka 5, 44-100 Gliwice; tel. 322372687; janusz.belok@polsl.pl
} 


\section{Wprowadzenie}

Poprzez stan komfortu cieplnego człowieka rozumiemy stan zrównoważonego bilansu cieplnego z otoczeniem, czyli ilość ciepła wytwarzanego w wyniku metabolizmu jest równa ilości ciepła traconego do otoczenia, przy jednoczesnym braku odczuwania dyskomfortu lokalnego. Na ów bilans cieplny wpływa aktywność fizyczna człowieka oraz izolacyjność cieplna odzieży, a także parametry środowiska: temperatura, wilgotność względna i prędkość przepływu powietrza, oraz średnia temperatura promieniowania. Znając te czynniki (oszacowanie lub pomiar) możliwe jest prognozowanie odczucia cieplnego całego ciała poprzez obliczenie wskaźnika PMV - tzw. przewidywanej średniej oceny przez dużą grupę osób w siedmio lub dziewięciostopniowej skali [1], [2], [3]. Wskaźnik PMV $=0$ określa stan równowagi cieplnej uznawany jako komfortowy. Komfort cieplny jest pojęciem subiektywnym. Jak wynika z przeprowadzonych badań, temperatury zapewniające dobre samopoczucie są zazwyczaj wyższe dla kobiet i osób starszych niż dla mężczyzn i osób młodszych. Ponadto, przyjmuje się, że zimą dla osoby ubranej zakres temperatur powietrza zapewniających dobre samopoczucie wynosi $\mathrm{t}_{\mathrm{i}}=20 \div 23^{\circ} \mathrm{C}$, natomiast latem ze względu na „lżejsze” ubranie $t_{i}=24 \div 28^{\circ} \mathrm{C}[1]$.

Do oceny komfortu cieplnego jest stosowana średnia temperatura promieniowania oraz temperatura operacyjna. Temperatura operacyjna jest definiowana jako jednorodna temperatura teoretycznego czarnego pomieszczenia, w którym człowiek wymienia te sama ilość ciepła przez promieniowanie i konwekcje, jak $w$ rzeczywistym, niejednorodnym środowisku [2]. Średnia temperatura promieniowania jest określana jako jednorodna temperatura pomieszczenia, w którym człowiek wymienia na drodze promieniowania taką samą ilość ciepła jak w rzeczywistym, niejednorodnym środowisku.

W zakresie komfortu cieplnego oszklenie ma wpływ na temperaturę pomieszczenia, średnią temperaturę promieniowania oraz warunki oświetleniowe. Jakość energetyczna zestawów szybowych (niska izolacyjność termiczna) wpływa na zmniejszenie temperatury operacyjnej $\mathrm{w}$ stosunku do temperatury powietrza. Z kolei zapewnienie wysokiej temperatury w pomieszczeniu nie musi oznaczać zagwarantowania warunków komfortu cieplnego. Brak jego odczuwania może być spowodowany niepożądanym nagrzaniem lub nadmiernym ochłodzeniem określonej części ciała (miejscowy dyskomfort termiczny). Może to być wywołane przeciągiem, zbyt dużą różnicą temperatury w pionie między głową i kostkami u nóg, zbyt ciepłą lub chłodną podłogą oraz zbyt dużą asymetrią temperatury promieniowania. Należy zatem zauważyć, że średnia temperatura promieniowania, a tym samym temperatura operacyjna zależą od usytuowania człowieka względem powierzchni o obniżonej lub podwyższonej temperaturze [1], [2].

W niniejszym artykule autorzy podjęli próbę określenia wpływu wybranych parametrów oszklenia na komfort cieplny w strefie o regulowanej temperaturze. 


\section{Opis procedury badawczej}

\subsection{Opis programu symulacyjnego i założenia analiz}

Metoda badawcza przyjęta $\mathrm{w}$ pracy to badania numeryczne $\mathrm{z}$ wykorzystaniem programów EnergyPlus, Window oraz OpenStudio [3], [4], [5]. Za ich pomocą można modelować parametry energetyczne i optyczne okien, fasad przeszklonych oraz wyznaczać zużycie energii na potrzeby ogrzewania, chłodzenia, wentylacji, oświetlenia oraz zużycia ciepłej wody w budynkach. Ponadto dają możliwość modelowania oświetlenia pomieszczeń (wyznaczenie natężenia oświetlenia, iluminancji, olśnienia w wybranych punktach analizowanej strefy) z uwzględnieniem elementów zacieniających. Istnieje także możliwość określenia komfortu cieplnego w analizowanej strefie. Analizy bazują na wykorzystaniu metody MES w powiązaniu z implementacją równań empirycznych dla zjawisk nie opisanych w inny sposób. Obliczenia prowadzone są z godzinowym krokiem czasowym na bazie rzeczywistych danych klimatycznych. W analizach wykorzystano bazę danych klimatycznych dla miasta Katowice, stacja aktynometryczna - Chorzów wraz z jej analizą statystyczną i wytypowanymi dniami projektowymi, udostępnianą przez [3]. Charakterystycznymi datami ilustrującymi skrajne warunki pogodowe dla wybranej lokalizacji w ciągu roku są dni: 21.01 oraz 21.07 [3]. Dane klimatyczne zostały zebrane w okresie lat $1971 \div 2000$.

Założenia przyjęte $\mathrm{w}$ analizach:

- rodzaj budynku: mieszkalny,

- strumień objętości powietrza wentylacyjnego $\mathrm{V}_{\text {inf }}=20 \mathrm{~m}^{3} / \mathrm{h} \cdot$ osoba,

- liczba osób: $\mathrm{n}=2$,

- zyski ciepła od źródeł wewnętrznych przyjęto zgodnie z [6] dla budynku jednorodzinnego $\mathrm{q}_{\mathrm{int}}=6,8 \mathrm{~W} / \mathrm{m}^{2}$, od oświetlenia $\mathrm{q}_{\text {electr }}=5,0 \mathrm{~W} / \mathrm{m}^{2}$,

- system c.o.: kocioł gazowy, grzejniki konwekcyjne,

- system wentylacji: mechaniczna z odzyskiem ciepła,

- temperatura w pomieszczeniu w zimie $20^{\circ} \mathrm{C}$, w okresie letnim $26^{\circ} \mathrm{C}$.

Wentylacja pracuje zgodnie z powyżej opisanymi założeniami, z możliwością okresowego zwiększenia wymiany powietrza celem wychłodzenia budynku. Temperatura dla okresu letniego nie jest regulowana poprzez system aktywnego chłodzenia (wytwarzanie chłodu). Przyjęto, że chłodzenie budynku odbywa się poprzez intensyfikację wentylacji (intensywna wentylacja w okresie nocnym). Jeżeli temperatura powietrza w budynku przekroczy $26^{\circ} \mathrm{C}$, a temperatura powietrza zewnętrznego jest od niej niższa, wówczas następuje zwiększenie wymian powierza do 3/h. Chcąc uzyskać wyniki dla budynku pod pełnym obciążeniem cieplnym wprowadzono zyski ciepła od oświetlenia i źródeł wewnętrznych. Ich wartości przyjęto sugerując się danymi zawartymi w [6], z uwagi na znaczne rozbieżności tych danych w literaturze. Obliczenia były realizowane według odrębnego algorytmu [3], niezwiązanego z [6]. 
W celu określenia komfortu cieplnego posłużono się wskaźnikiem PMV. Do obliczeniowego ustalenia wartości tego wskaźnika przyjęto poniższe wartości wielkości opisujących rodzaj ubioru i sposób zachowania się człowieka [2]:

- aktywność fizyczna: met $=108 \mathrm{~W} /$ osobę $\mathrm{w}$ godz. $8^{00}-23^{00}$; met $=72 \mathrm{~W} /$ osobę w godz. $23^{00}-8^{00}$;

- oporność cieplna odzieży: zima: clo $=1,0 \mathrm{w}$ godz. $8^{00}-23^{00}$; clo $=1,5 \mathrm{w}$ godz. $23^{00}-8^{00}$; lato: clo $=0,5 \mathrm{w}$ godz. $8^{00}-23^{00}$; clo $=1,5 \mathrm{w}$ godz. $23^{00}-8^{00}$;

- prędkość przepływu powietrza, $\mathrm{w}_{\mathrm{air}}=0,1 \mathrm{~m} / \mathrm{s}$.

\subsection{Przedmiot analiz i charakterystyka wariantów}

Przedmiotem pracy jest budynek jednorodzinny parterowy z poddaszem użytkowym, niepodpiwniczony, wykonany w technologii tradycyjnej murowanej. Na parterze znajdują się pokój dzienny połączony z kuchnią, wc, wiatrołap. $\mathrm{Na}$ poddaszu zlokalizowano trzy sypialnie oraz łazienkę. Powierzchnia ogrzewana wynosi $109,59 \mathrm{~m}^{2}$. Od strony zachodniej został dobudowany garaż, który jest nieogrzewany $\left(41,43 \mathrm{~m}^{2}\right)$. W tab. 1 zestawiono współczynniki przenikania ciepła przegród nieprzezroczystych, spełniające aktualne wymagania izolacyjności termicznej zawarte w [7]. Na rys. 1 przedstawiono widok elewacji budynku.

Tabela 1. Współczynniki przenikania ciepła przegród nieprzezroczystych

Table 1. Thermal transmittance coefficients of building's opaque partitions

\begin{tabular}{|c|c|}
\hline Rodzaj przegrody & Współczynnik przenikania ciepła $\mathbf{U}\left[\mathbf{W} / \mathbf{m}^{\mathbf{2}} \mathbf{K}\right]$ \\
\hline podłoga na gruncie & 0,21 \\
\hline ściana zewnętrzna & 0,12 \\
\hline dach & 0,14 \\
\hline drzwi wejściowe & 0,79 \\
\hline
\end{tabular}

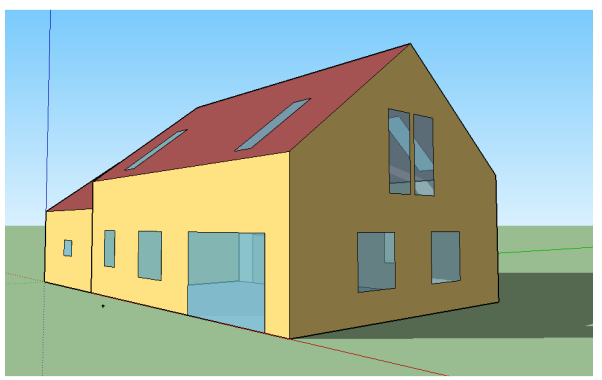

(a)

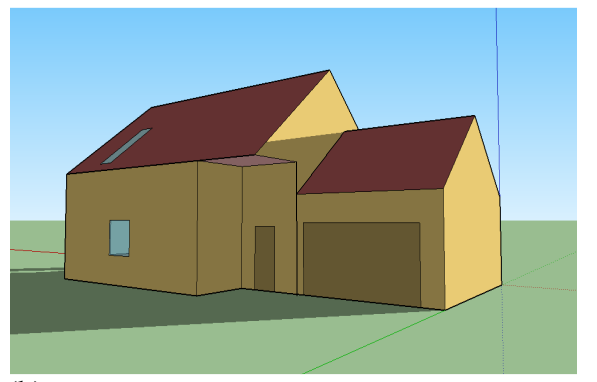

(b)

Rys. 1. Widok analizowanego budynku: (a) elewacja południowowschodnia, (b) elewacja północno-zachodnia

Fig. 1. View of analyzed building: (a) S-E elevation, (b) N-W elevation 
W celu określenia wpływu parametrów oszklenia na komfort cieplny w wybranej strefie o regulowanej temperaturze przeprowadzono badania porównawcze. Rozpatrzono 4 warianty oszklenia. Wariant wyjściowy W0 spełnia wymagania izolacyjności termicznej stawiane przegrodom przezroczystym do 2014 r. Pozostałe warianty dobrano tak, aby odpowiadały aktualnym rozwiązaniom technicznym, spełniały aktualne wymagania izolacyjności termicznej [7], ale różniły się wartością współczynników: przenikania ciepła $U$, całkowitej przepuszczalności energii promieniowania słonecznego g oraz przepuszczalności światła $\tau_{\text {vis }}$ [4], [7], [8]. W tab. 2 zestawiono parametry dla poszczególnych wariantów.

Tabela 2. Charakterystyka analizowanych wariantów

Table 2. Characteristic of analyzed variants

\begin{tabular}{|c|c|c|c|c|}
\hline Wariant & $\begin{array}{c}\text { Schemat } \\
\text { zestawu } \\
\text { szybowego }\end{array}$ & $\begin{array}{c}\text { Współczynnik } \\
\mathbf{g}[-]\end{array}$ & $\begin{array}{c}\text { Współczynnik } \\
\boldsymbol{\tau}_{\text {vis }}[-]\end{array}$ & $\begin{array}{c}\text { Współczynnik } \\
\mathbf{U}\left[\mathbf{W} / \mathbf{m}^{2} \mathbf{K}\right]\end{array}$ \\
\hline $\mathrm{W} 0$ & $\begin{array}{c}(4-18-4) \\
\text { W }\end{array}$ & 0,79 & 0,82 & 2,71 \\
\hline $\mathrm{W} 2$ & 0,71 & 0,74 & 1,64 \\
\hline $\mathrm{W}$ & $(4-18-4-18-4)$ & 0,60 & 0,72 & 0,65 \\
\hline & $(4-18-4-18-6)$ & 0,34 & 0,43 & 0,71 \\
\hline
\end{tabular}

Wariant W0 to zestaw jednokomorowy złożony z szyb zwykłych, z wypełnieniem komory międzyszybowej powietrzem. Warianty $\mathrm{W} 1 \div \mathrm{W} 3$ to zestawy trójszybowe, w których komory są wypełnione argonem. W1 to zestaw złożony z szyb zwykłych, W2 - szyby zwykłe z powłokami niskoemisyjnymi, natomiast W3 od strony zewnętrznej szkło z powłoką przeciwsłoneczną oraz od wewnętrznej strony z powłoką niskoemisyjną.

\section{Wyniki badań $\mathrm{i}$ ich analiza}

W efekcie przeprowadzonych obliczeń uzyskano szereg wyników obrazujących zachowanie się modelu pod obciążeniem cieplnym wywołanym klimatem zewnętrznym. $\mathrm{Z}$ punktu widzenia celu jakiemu podporządkowane były badania, uzyskane wyniki obliczeń, dla założeń opisanych w rozdziale 2, przedstawiają wykresy na rys. $2 \div 4$. Najbardziej korzystnym wariantem pod względem speł- 
nienia wymagań komfortu cieplnego (PMV) zarówno dla okresu zimowego, jak i letniego wydaje się być wariant W3 (por. rys. 2). W pozostałych przypadkach w odniesieniu do skali PMV - mamy do czynienia odpowiednio z odczuwaniem zimna (W_Z-21.01) lub ciepła (W_L - 21.07).

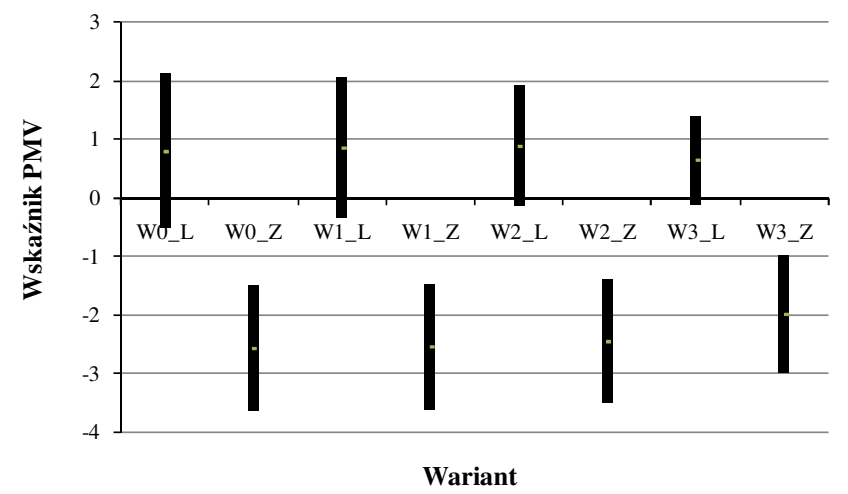

Rys. 2. Przedziały zmienności wskaźnika PMV w dniu 21.07 (W_L) oraz 21.01(W_Z)

Fig. 2. PMV index variation ranges on July $21^{\text {st }}$ (W_L) and January $21^{\text {st }}\left(\mathrm{W} \_Z\right)$

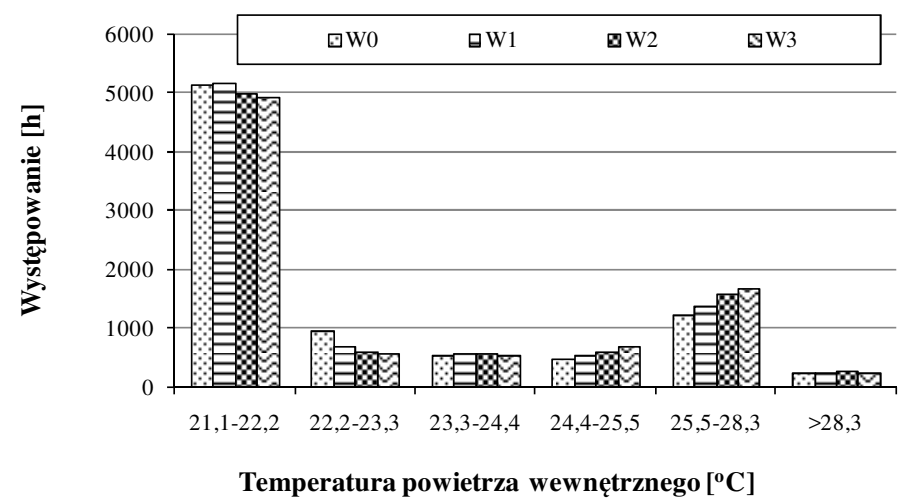

Rys. 3. Liczba godzin występowania dla danego przedziału temperatur

Fig. 3. The number of hours of occurrence for a given temperature range

Największą liczbę godzin występowania obserwujemy dla zakresu temperatury powietrza $21,1 \div 22,2^{\circ} \mathrm{C}$, natomiast najniższą liczbę dla temperatur powyżej $28,3^{\circ} \mathrm{C}$ (różnice między poszczególnymi wariantami są nieznaczne). Rozpatrując przedziały z temperaturami powietrza powyżej $24,4^{\circ} \mathrm{C}$ najwyższa liczba godzin występowania przypada dla wariantu W3. Dla przedziałów z temperaturą powietrza poniżej $21,1^{\circ} \mathrm{C}$ najniższa liczba godzin występowania przypada dla W3 (8h), natomiast najwyższa dla W0 (34h). 


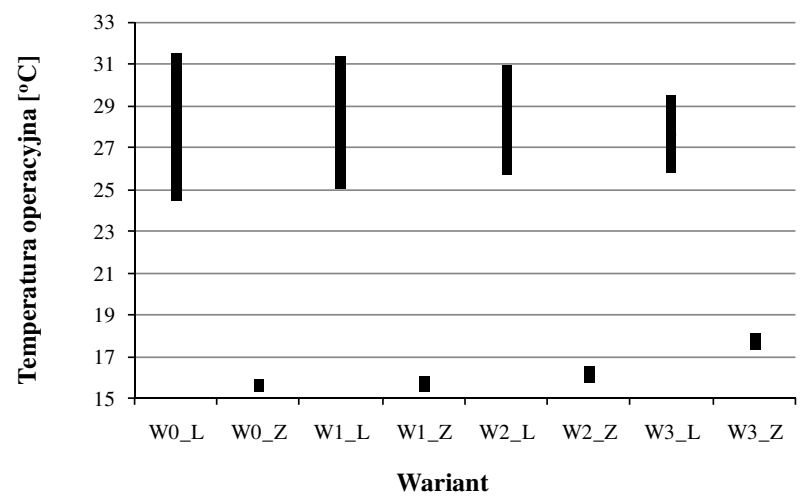

Rys. 4. Zakresy temperatury operacyjnej w dniu 21.07 (W_L) oraz 21.01 (W_Z)

Fig. 4. Range of operative temperature on July $21^{\text {st }}\left(\mathrm{W} \_L\right)$ and January $21^{\text {st }}\left(\mathrm{W} \_Z\right)$

Analizując wartości temperatury operacyjnej $\left(t_{\mathrm{OP}}\right)$ najbardziej korzystne przedziały występują dla wariantu W3, zarówno w okresie letnim jak i zimowym, najmniej korzystne dla W0. W okresie letnim temperatura $t_{\mathrm{OP}}$ zawiera się w przedziale $24,45 \div 31,54^{\circ} \mathrm{C}$ dla $\mathrm{W} 0$, natomiast dla W3 $25,79 \div 29,48^{\circ} \mathrm{C}$. Różnice wartości temperatury $\mathrm{t}_{\mathrm{OP}}$ dla tych wariantów nie są znaczące, natomiast koszty inwestycyjne różnią się znacznie. Dla okresu zimowego występują znacznie większe różnice temperatur, dla wariantu W0 zakres wynosi $15,27 \div$ $15,92^{\circ} \mathrm{C}$, a dla $\mathrm{W} 317,33 \div 18,09^{\circ} \mathrm{C}$. Na końcowy efekt energetyczny i odczucie komfortu cieplnego składa się zatem wypadkowe współdziałanie parametrów optyczno-energetycznych (U oraz g) oszkleń (nie należy kierować się tylko jednym z parametrów). Widoczny jest tutaj także wpływ temperatury powierzchni oszklenia na temperaturę operacyjną w pomieszczeniu.

\section{Podsumowanie}

Zakres temperatury powietrza wewnętrznego, w którym człowiek odczuwa komfort cieplny jest bardzo zróżnicowany. Zależy on przede wszystkim od indywidualnych preferencji, wieku, płci, rodzaju ubrania, stopnia aktywności fizycznej oraz pory roku. Ze względu na indywidualne różnice nie jest możliwe określenie środowiska termicznego, które będzie satysfakcjonowało każdą osobę. Istnieje natomiast możliwość doboru środowiska, które będzie przewidywalnie akceptowalne dla określonego odsetka użytkowników.

Zdaniem autorów zjawisko komfortu cieplnego powinno być uwzględniane już na etapie projektowania obiektu budowlanego, szczególnie w przypadku obiektów o dużych powierzchniach przeszklonych, celem optymalizacji w zakresie rozwiązań architektoniczno-budowlano-instalacyjnych. 


\title{
Literatura
}

[1] Fanger P.O., Popiołek Z., Wargocki P.: Środowisko wewnętrzne: wpływ na zdrowie, komfort i wydajność pracy, Wydawnictwo Politechniki Śląskiej 2003.

[2] PN EN ISO 7730: 2006: Ergonomia środowiska termicznego. Analityczne wyznaczanie i interpretacja komfortu termicznego z zastosowaniem obliczania wskaźników PMV i PPD oraz kryteriów miejscowego komfortu termicznego.

[3] http://bigladdersoftware.com/epx/docs/8-0/input-output-reference/page-094.html \{dostęp 10.05.2016 r.\}.

[4] https://windows.lbl.gov/software/comfen/comfen.html \{dostęp 10.05.2016 r.\}.

[5] https://www.openstudio.net/ \{dostęp 10.05.2016 r.\}.

[6] Rozporządzenie MIiR z dn. 18.03.2015 r. w sprawie metodologii wyznaczania charakterystyki energetycznej budynku lub części budynku ... Dz. U. z 2015 r. poz. 376.

[7] Rozporządzenie MIiR z dn. 17.07.2015 r. w sprawie warunków technicznych, jakim powinny odpowiadać budynki i ich usytuowanie, Dz.U. z 2015 r. poz. 1422.

[8] EN ISO 10077-1.: Cieplne właściwości użytkowe okien, drzwi i żaluzji - obliczanie współczynnika przenikania ciepła. Cz. 1.: Postanowienia ogólne.

\section{GLAZING PARAMETERS VS. THERMAL COMFORT IN A ZONE WITH ADJUSTABLE TEMPERATURE}

\begin{abstract}
S u m m a r y
The goal of this paper was to determine the impact of glazing parameters on thermal comfort in a building. A part of detached building with heated area of approx. $110 \mathrm{~m}^{2}$ with large glazed area from southern side was selected as such a zone. There was chosen as testing method the numerical method - EnergyPlus, OpenStudio and Window software. Climate data necessary for calculations were taken for Katowice. It was assumed that in the building operates mechanical ventilation system with heat recovery and heating installation with a gas boiler and panel convection radiators. Estimation of thermal comfort was carried out using PMV index. In considerations were taken into account seasons (summer, winter) and time of day (day, night) by taking suitable values describing man physical activity (met) and thermal resistance of clothing (clo). 4 variants of glazing were used in the analysis. The reference point was the glazed façade made of single chamber pane set filled with air. Other variants were selected in such a way that they corresponded to modern solutions of pane sets assigned for low-energy buildings. They meet current requirements of thermal insulating power but they have different values of the following coefficients: thermal transmittance $U$, total permeability of solar radiation energy g and light transmittance $\tau_{\text {vis }}$. They are sets with three glasses and with chambers filled with argon and the panes are covered with selective coats. From the point of view of feeling thermal comfort for described above assumptions it seems that the most advantageous is W3 solution.
\end{abstract}

Keywords: PMV index, thermal resistance of clothing, man physical activity, average radiation temperature of surrounding partitions

DOI:10.7862/rb.2016.235

Przestano do redakcji: 11.07.2016 $r$.

Przyjęto do druku: 30.11.2016 r. 